\title{
Changes in nutrient stoichiometry, elemental homeostasis and growth rate of aquatic litter- associated fungi in response to inorganic nutrient supply
}

\author{
Vladislav Gulis ${ }^{1}$, Kevin A Kuehn ${ }^{2}$, Louie N Schoettle ${ }^{1}$, Desiree Leach ${ }^{1}$, Jonathan P Benstead ${ }^{3}$ \\ and Amy D Rosemond ${ }^{4}$ \\ ${ }^{1}$ Department of Biology, Coastal Carolina University, Conway, SC, USA; ${ }^{2}$ Department of Biological Sciences, \\ University of Southern Mississippi, Hattiesburg, MS, USA; ${ }^{3}$ Department of Biological Sciences, University of \\ Alabama, Tuscaloosa, AL, USA and ${ }^{4}$ Odum School of Ecology, University of Georgia, Athens, GA, USA
}

\begin{abstract}
Aquatic fungi mediate important energy and nutrient transfers in freshwater ecosystems, a role potentially altered by widespread eutrophication. We studied the effects of dissolved nitrogen $(\mathrm{N})$ and phosphorus $(P)$ concentrations and ratios on fungal stoichiometry, elemental homeostasis, nutrient uptake and growth rate in two experiments that used (1) liquid media and a relatively recalcitrant carbon (C) source and (2) fungi grown on leaf litter in microcosms. Two monospecific fungal cultures and a multi-species assemblage were assessed in each experiment. Combining a radioactive tracer to estimate fungal production (C accrual) with $N$ and $P$ uptake measurements provided an ecologically relevant estimate of mean fungal $C: N: P$ of 107:9:1 in litter-associated fungi, similar to the 92:9:1 obtained from liquid cultures. Aquatic fungi were found to be relatively homeostatic with respect to their $C: N$ ratio $(\sim 11: 1)$, but non-homeostatic with respect to $C: P$ and $N: P$. Dissolved $N$ greatly affected fungal growth rate and production, with little effect on C:nutrient stoichiometry. Conversely, dissolved $\mathbf{P}$ did not affect fungal growth and production but controlled biomass $\mathrm{C}: \mathrm{P}$ and $N: P$, probably via luxury $P$ uptake and storage. The ability of fungi to immobilize and store excess $P$ may alter nutrient flow through aquatic food webs and affect ecosystem functioning.

The ISME Journal (2017) 11, 2729-2739; doi:10.1038/ismej.2017.123; published online 21 July 2017
\end{abstract}

\section{Introduction}

Relative and absolute availability of nitrogen $(\mathrm{N})$ and phosphorus (P) in ecosystems has changed as a result of human activity (Millennium Ecosystem Assessment, 2005). Little is known about the responses of heterotrophic microorganisms, especially aquatic fungi, to these shifts in nutrient availability. Apart from limiting the metabolic activity of microorganisms, $\mathrm{N}$ and $\mathrm{P}$ can also affect nutrient content of microbial biomass. Demand from microorganisms for energy and nutrients links their production to the cycling of $\mathrm{C}, \mathrm{N}$ and $\mathrm{P}$ within ecosystems (Sinsabaugh and Follstad Shah, 2012; Sinsabaugh et al., 2015). Thus, C, N and P cycling by microorganisms is partly controlled by the elemental composition of their biomass, making knowledge of the effects of increased exogenous nutrient availability on biomass stoichiometry, its variability and

Correspondence: V Gulis, Department of Biology, Coastal Carolina University, PO Box 261954, Conway, SC 29528-6054, USA.

E-mail: vgulis@coastal.edu

Received 20 September 2016; revised 16 May 2017; accepted 14 June 2017; published online 21 July 2017 on microbial activity (for example, growth rate) essential for understanding the role of microbes in nutrient cycles. Unfortunately, data on elemental stoichiometry and the degree of homeostasis in aquatic litter-associated microorganisms are scarce (Newell and Statzell-Tallman, 1982; Sanzone et al., 2001; Findlay et al., 2002). Virtually nothing is known about the stoichiometry, elemental homeostasis and responses to nutrients in aquatic fungi, despite their key role in litter processing (Gessner et al., 2007; Danger et al., 2016; Kuehn, 2016). Fungal biomass accrual and associated immobilization of $\mathrm{N}$ and $\mathrm{P}$ lead to strong control by fungi of C:N and C:P stoichiometry of decomposing plant litter (Tant et al., 2013; Cornut et al., 2015; Manning et al., 2015). These increases in fungal biomass and nutrient content of detritus improve resource quality for detritivorous invertebrates, facilitating $C$ and nutrient flow to higher trophic levels (Cross et al., 2006, 2007).

Recent studies of freshwater bacteria suggest that both individual strains and natural assemblages can be stoichiometrically highly flexible, especially with respect to their C:P and N:P ratios (Cotner et al., 
2010; Scott et al., 2012; Godwin and Cotner, 2014, 2015). Fanin et al. (2013) observed non-homeostasis in $\mathrm{C}: \mathrm{P}$ and $\mathrm{N}: \mathrm{P}$, but not $\mathrm{C}: \mathrm{N}$, ratios in natural microbial communities within a terrestrial plant litter-microbe system that had roughly comparable contributions of fungi and bacteria. A recent study using laboratory microcosms showed that pure cultures of aquatic hyphomycetes are nonhomeostatic (Danger and Chauvet, 2013). However, the use of a highly labile C source (glucose) and unrealistically high levels of dissolved $\mathrm{N}$ and $\mathrm{P}$ may limit generalization of this experimental finding.

Initial stoichiometric ratios of leaf litter entering streams (C:N> 50, C:P > 500; Enriquez et al., 1993; Manning et al., 2015) are considerably higher than C: nutrient ratios of microbial biomass (Sterner and Elser, 2002). Thus, from the perspective of stoichiometric imbalance, and because carbon use efficiency of leaf litter-associated fungi is often quite high (averaging around 33\%, but reaching 60\% at high $\mathrm{N}$ and P availability; Suberkropp, 1991; Gulis and Suberkropp, 2003c), these microorganisms must either retain $\mathrm{N}$ and $\mathrm{P}$ from organic substrates more efficiently than $\mathrm{C}$, or immobilize inorganic nutrients from stream water. Fungi, such as aquatic hyphomycetes, that dominate microbial communities on decaying plant litter in streams (Gessner et al., 2007; Kuehn, 2016) are known to obtain N and P from both their substrate and the water column (Suberkropp, 1995; Cheever et al., 2013). Mining $\mathrm{N}$ and $\mathrm{P}$ from organic substrates requires considerable energy and resource expenditure to produce extracellular enzymes to attack recalcitrant molecules and cleave amino or phosphate groups (Sinsabaugh et al., 2014). Thus, fungi should preferentially use dissolved inorganic nutrients when available. Indeed, experiments in laboratory microcosms and whole-stream nutrient additions have shown that elevated dissolved nutrient concentrations stimulate fungal activity (that is, growth and sporulation rates, maximum fungal biomass, cumulative production, respiration) and litter decomposition (Gulis and Suberkropp, 2003a,b; Ferreira et al., 2006; Gulis et al., 2008; Suberkropp et al., 2010; Rosemond et al., 2015). However, in most of these experiments, both $\mathrm{N}$ and $\mathrm{P}$ were added, often at single levels of concentration. Thus, the possible differential responses of biomass nutrient stoichiometry vs activity (for example, growth rate) of aquatic fungi to gradients of dissolved $\mathrm{N}$ and $\mathrm{P}$ are poorly understood.

Here, we present results from two experiments designed to estimate elemental stoichiometry of aquatic fungi (C:N, C:P and $\mathrm{N}: \mathrm{P}$ ratios), as well as the degree of elemental homeostasis under realistic conditions of $\mathrm{N}$ and $\mathrm{P}$ enrichment. In the second experiment, we also contrasted the effects of $\mathrm{N}$ and $\mathrm{P}$ on fungal stoichiometry with their effects on fungal growth and production. Both experiments included monocultures and multi-species fungal assemblages. In the first experiment, aquatic fungi were grown in liquid media with varying concentrations and ratios of dissolved inorganic $\mathrm{N}$ and $\mathrm{P}$ and a relatively recalcitrant soluble $\mathrm{C}$ source (carboxymethylcellulose). Fungal biomass $\mathrm{C}, \mathrm{N}$ and $\mathrm{P}$ contents were determined directly. The second experiment involved culturing fungi on a natural substrate (leaf litter) in microcosms simulating stream conditions at realistic levels of dissolved $\mathrm{N}$ and $\mathrm{P}$ availability. Nutrient stoichiometry of biomass was estimated from fungal $\mathrm{C}$ production $\left({ }^{14} \mathrm{C}\right.$-labeling) and dissolved $\mathrm{N}$ and $\mathrm{P}$ uptake over short intervals; fungal growth rates and production were also related to nutrient availability.

\section{Materials and methods}

\section{Dissolved nutrient treatments}

In Experiment 1, physiological responses of aquatic hyphomycetes to different concentrations and ratios of dissolved inorganic $\mathrm{N}$ and $\mathrm{P}$ were followed in liquid media with a soluble C source (Figure 1, Supplementary Table S1). Fourteen nutrient treatments included seven N:P ratios (2:1 to $128: 1)$ at low and high nutrient concentration levels. Since these were batch cultures, initial concentrations were set relatively high. However, calculations based on biomass yield and reasonable average C:N:P expectations (Redfield ratio), as well as preliminary experiments, indicated that after 3-week incubations in some treatments all $\mathrm{N}$ or $\mathrm{P}$ would be incorporated into fungal biomass. In Experiment 2, aquatic fungi were grown on leaf litter in microcosms simulating stream conditions. Fungi were incubated at nine levels of dissolved nutrient availability (plus control, no added nutrients; Figure 1, Supplementary Table S2). Nutrient solutions spanned realistic N:P ratios $(4: 1$ to $64: 1)$ at three levels of nutrient concentrations $\left(\mathrm{NO}_{3}-\mathrm{N}, \quad 36-1445 \mu \mathrm{gl}^{-1} ; \quad \mathrm{PO}_{4}-\mathrm{P}\right.$, 8-125 $\mathrm{\mu g} \mathrm{l}^{-1}$ ) found in pristine to polluted streams (Allan, 1995; Dodds and Welch, 2000). In both experiments, $\mathrm{N}$ and $\mathrm{P}$ were added as sterile solutions of $\mathrm{NaNO}_{3}$ and $\mathrm{KH}_{2} \mathrm{PO}_{4}$, respectively. Note, however, that in Experiment 1, initially high nutrient concentrations decreased during 3-week incubations due to fungal uptake, while in Experiment 2, solutions were replaced every 2 days to maintain low nutrient concentrations naturally found in streams.

\section{Fungal inocula}

In both experiments, three fungal treatments were used: two monocultures (Tricladium chaetocladium 27-1, TC; Heliscus lugdunensis 62-1, HL) and a 6- or 7-species fungal assemblage (TC, HL, Anguillospora filiformis 23-4, Articulospora tetracladia 24-4, Dimorphospora foliicola 62-4, Flagellospora sp. 31-4, Tetrachaetum elegans 24-1; the last species was omitted in Experiment 2). All pure cultures were isolated from single conidia from decomposing leaf litter collected from streams at the Coweeta Long 

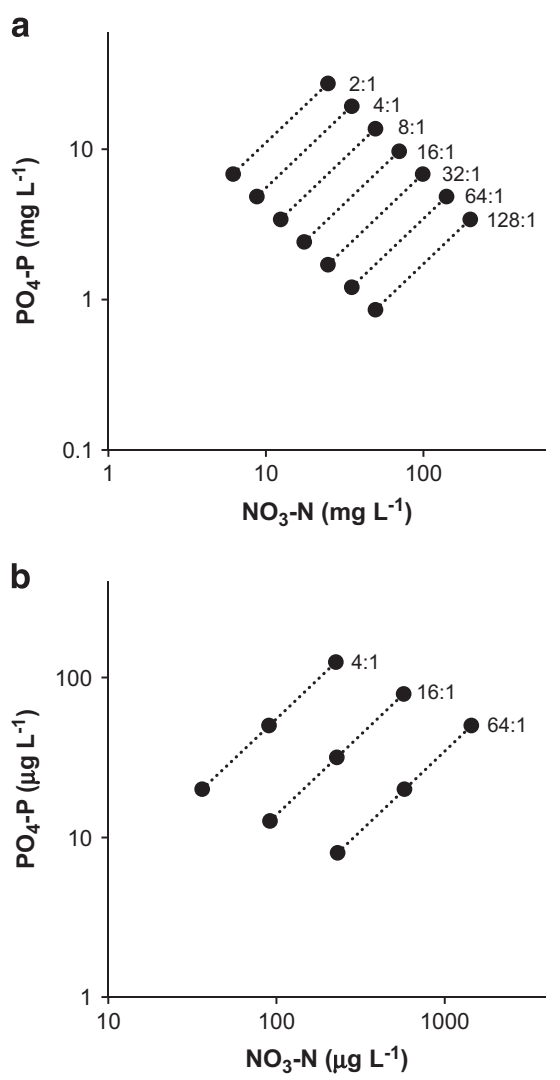

Figure 1 Concentrations of dissolved inorganic nitrogen $\left(\mathrm{NO}_{3}-\mathrm{N}\right)$ and phosphorus $\left(\mathrm{PO}_{4}-\mathrm{P}\right)$ and $\mathrm{N}: \mathrm{P}$ ratios (molar) used in (a) Experiment 1 with fungi grown in liquid media and a soluble $\mathrm{C}$ source and (b) Experiment 2 with fungi grown on leaf litter in microcosms simulating natural stream conditions.

Term Ecological Research site (Otto, NC, USA). Experimental microcosms were inoculated with suspensions of conidia obtained by inducing sporulation from pure cultures. Growing colonies were kept at $15{ }^{\circ} \mathrm{C}$ in Petri dishes containing $1 \%$ malt extract and $2 \%$ agar (Difco, Sparks, MD, USA) for 3 weeks, at which point production of conidia was induced by agitation of agar slivers from fungal colonies in $25 \mathrm{ml}$ of sterile deionized water on an orbital shaker (100 rpm) (Gulis and Suberkropp, 2003b). After 3 days, appropriate aliquots of conidia suspensions were used as inocula at $\sim 600$ conidia per microcosm.

Experiment 1. Aquatic fungi grown in liquid media The base liquid medium used in this experiment contained carboxymethylcellulose (sodium salt) $8.38 \mathrm{~g}, \mathrm{CaCl}_{2} 0.1 \mathrm{~g}, \mathrm{MgSO}_{4} \times 7 \mathrm{H}_{2} \mathrm{O} 0.1 \mathrm{~g}, \mathrm{MnSO}_{4} \times 7$ $\mathrm{H}_{2} \mathrm{O} 0.004 \mathrm{~g}, \mathrm{FeCl}_{3} \times 6 \mathrm{H}_{2} \mathrm{O} 0.01 \mathrm{~g}$, thiamine $0.01 \mathrm{mg}$ (per $1 \mathrm{l}$ ). $\mathrm{MgSO}_{4}$ and $\mathrm{CaCl}_{2}$ were autoclaved separately, while micronutrients and thiamine were filter-sterilized. Inorganic nutrients ( $\mathrm{N}$ and $\mathrm{P}$ ) were added as sterile solutions of $\mathrm{NaNO}_{3}$ and $\mathrm{KH}_{2} \mathrm{PO}_{4}$, respectively, at 14 combinations of concentrations and ratios (Figure 1, Supplementary Table S1). Liquid media were aseptically dispensed $(25 \mathrm{ml})$ into 75-ml tissue culture flasks with vented caps and inoculated with fungal spores. The flasks were placed on an orbital shaker in an inverted position to prevent the attachment of fungal colonies and incubated at 125 r.p.m. at $20^{\circ} \mathrm{C}(16 / 8 \mathrm{~h} \mathrm{light/dark}$ cycle) in an environmental chamber for 24 days.

After the experiment was terminated, the contents of flasks were filtered through pre-combusted preweighed glass-fiber filters (Whatman 934-AH) to capture fungal mycelia and spores. Two filters per flask (for $\mathrm{N}$ and $\mathrm{P}$ analyses) were prepared and rinsed $4 \times$ with saline solution. Filters were dried at $60^{\circ} \mathrm{C}$ for at least $24 \mathrm{~h}$. The filters were then weighed to determine fungal biomass and analyzed for $\mathrm{N}$ or $\mathrm{P} . \mathrm{N}$ content of fungal biomass was determined with a CHN elemental analyzer at the Odum School of Ecology, University of Georgia, USA. P content of fungal biomass was determined using a modification of the combustion and hot $\mathrm{HCl}$ extraction procedure of Andersen (1976), followed by spectrophotometry using the ascorbic acid molybdenum blue method (APHA, 1995). National Institute of Standards and Technology standards for both $\mathrm{N}$ and $\mathrm{P}$ were used as a reference.

Experiment 2. Aquatic fungi grown on leaf litter in microcosms simulating stream conditions

Laboratory microcosms. Laboratory microcosms specifically designed and shown to simulate stream conditions (with respect to turbulence and aeration necessary to ensure growth of aquatic hyphomycetes on leaf litter; Suberkropp, 1991) were used to obtain sufficient leaf-associated fungal biomass. Microcosms (glass cylinder, $33 \mathrm{~mm}$ in diameter $\times 120 \mathrm{~mm}$ long with aeration and drain tubes attached and covered by a glass cap) were combusted overnight $\left(500{ }^{\circ} \mathrm{C}\right)$ and acid-washed before the experiments. Each chamber was stocked with pre-weighed leaf disks (11.2 $\mathrm{mm}$ in diameter) obtained from freshly abscised, air-dried red maple (Acer rubrum L.) leaves. Before the experiment, leaf disks were leached in deionized water overnight to remove excess nutrients, dried $\left(60^{\circ} \mathrm{C}\right)$ and weighed in groups of 30. Chambers stocked with dry leaf disks were autoclaved for $20 \mathrm{~min}$ at $121^{\circ} \mathrm{C}$. Microcosm solutions $(40 \mathrm{ml}$ ) were aseptically pipetted into chambers and the leaf disks were allowed to soak until saturated. Solutions contained inorganic $\mathrm{N}$ and $\mathrm{P}$ added as sterile stocks of $\mathrm{NaNO}_{3}$ and $\mathrm{KH}_{2} \mathrm{PO}_{4}$, respectively, at nine combinations of concentrations and ratios (Figure 1, Supplementary Table S2), as well as $0.25 \mathrm{gl}^{-1}$ of 3 -(N-morpholino) propanesulfonic acid to maintain $\mathrm{pH}$ of 7.0 throughout the experiment. Microcosms inoculated with appropriate fungal treatment (see above) were incubated at $15^{\circ} \mathrm{C}$ with aeration $(100 \mathrm{ml}$ sterile air per min, regulated with individual flow meters) to simulate stream conditions (Suberkropp, 1991). Every 2 days, nutrient solutions were aseptically drained from each chamber and replaced with fresh sterile 
solutions in order to maintain nutrient concentrations and ratios. After 15 days, leaf disks were aseptically removed for fungal production and nutrient uptake assays.

Fungal growth rate and production. Fungal growth rate and production were estimated from rates of ${ }^{14} \mathrm{C}$-acetate incorporation into ergosterol (Suberkropp and Weyers, 1996; Suberkropp and Gessner, 2005). Leaf disks (8) with associated fungal biomass underwent short-term $(5 \mathrm{~h})$ incubations with sodium $\left[1-{ }^{14} \mathrm{C}\right]$ acetate $(2.387 \mathrm{MBq}$ per sample; ViTrax, Placentia, CA, USA) in 15-ml centrifuge tubes with nine nutrient solutions (Figure 1, Supplementary Table S2; $10 \mathrm{ml}$ total volume, $5 \mathrm{~mm}$ acetate, in triplicate). Three sets of uninoculated disks in 3-(N-morpholino) propanesulfonic acid-buffered solution with no nutrients added, as well as formalin-killed controls, were also run. Tubes were incubated flat on a shaker at $15^{\circ} \mathrm{C}$. After incubation, tubes were placed on ice, centrifuged $(5 \mathrm{~min}$ at $1000 \mathrm{~g}, 4^{\circ} \mathrm{C}$ ), the supernatant decanted into separate tubes for nutrient analyses, and then frozen. Leaf disks were later lyophilized, weighed and used for quantification of radiolabeled ergosterol.

Fungal biomass associated with leaf disks was estimated by ergosterol extraction and quantification by high-performance liquid chromatography. Ergosterol was extracted using the solid-phase extraction technique (modified from Gessner and Schmitt, 1996) using Oasis HLB 3cc cartridges (Waters, Milford, MA, USA; Gessner, 2005). Final elution of ergosterol was achieved with four portions (300-400 $\mathrm{\mu l}$ each) of isopropanol and the volume in each vial was then calculated based on weight and specific density $\left(\delta_{\text {isopropanol }}=0.786 \mathrm{~g} \mathrm{~cm}^{-3}\right.$ at $\left.25^{\circ} \mathrm{C}\right)$. Ergosterol content was determined via highperformance liquid chromatography (Shimadzu 10VP equipped with a Whatman Partisphere C18 reverse-phase column set at $40^{\circ} \mathrm{C}$ ). The UV detector was set at $282 \mathrm{~nm}$ and the flow rate of $100 \%$ methanol at $1 \mathrm{ml} \mathrm{min}^{-1}$. Two $100-\mu \mathrm{l}$ injections per sample were used. A standard curve based on external ergosterol standards (Acros Organics, Morris Planes, NJ, USA) was used to convert highperformance liquid chromatography areas to ergosterol concentrations. Ergosterol content per sample was calculated using the volume of lipid extract. A conversion factor of $4.5 \mathrm{mg}$ ergosterol per g fungal dry mass was used to estimate fungal biomass of H. lugdunensis (Raviraja et al., 2004) and $5.5 \mathrm{mg} \mathrm{g}^{-1}$ for all other species (Gessner and Chauvet, 1993).

For each sample, ergosterol fractions from two injections were collected (Advantec SF-3120), pooled in a $20-\mathrm{ml}$ scintillation vial, mixed with Ecolume scintillation cocktail (ICN Biomedicals, Cleveland, OH, USA) and assayed for radioactivity using a scintillation counter (Beckman LS-6500, Fullerton, CA, USA) that corrected for quenching. Instantaneous growth rates and fungal production were calculated assuming the exponential growth model (Gessner and Chauvet, 1997). This procedure also allowed to estimate the amount of fungal $\mathrm{C}$ produced during our short 5-h incubations. Data on fungal C production together with fungal dissolved $\mathrm{N}$ and P uptake data (see below) were used to calculate fungal elemental ratios (C:N:P).

Nutrient uptake rates. Fungal nutrient uptake per sample (or per unit of newly produced fungal C, see above) was estimated from the difference between the initial and final (after 5-h incubation) nutrient concentrations for each sample $(10 \mathrm{ml}$ solution in a tube). Owing to the radioactivity in our samples, a Hach kit 2429800 and a modification of the Hach method 8192 (scaled down 10-fold to run smaller samples) was used according to the manufacturer's suggestions to determine nitrate concentrations (Hach, Loveland, CO, USA). The method is based on nitrate Cd reduction followed by spectrophotometric determination of the colored product at $507 \mathrm{~nm}$. Soluble reactive phosphorus (SRP) was estimated by spectrophotometry using the ascorbic acid molybdenum blue method (APHA, 1995). For both nitrate-N and SRP, final absorbance values were corrected for color that leached from leaf litter during sample handling, and nutrient concentrations were then calculated based on standard curves.

\section{Data analyses}

Molar nutrient ratios of fungal biomass were estimated directly in Experiment 1 from C, N, P content of biomass captured on filters. Filter blanks were processed along with the samples and values were corrected. In Experiment 2, stoichiometric ratios of fungal biomass were calculated based on $\mathrm{C}$ production and simultaneous estimates of dissolved inorganic $\mathrm{N}$ and $\mathrm{P}$ uptake over the 5-h incubations. Fungal nutrient uptake rates were corrected using values from control samples incubated in solutions with no added nutrients. Since dissolved nutrient concentrations or their levels (low, medium and high) could not be the same among nutrient ratio treatments $(4: 1,16: 1$ and 64:1) in our experimental design (Figure 1), we could use only a regression approach (not ANOVA) for the full data sets. Specifically, the effects of dissolved nutrient ratios or concentrations $\left(\mathrm{NO}_{3}-\mathrm{N}\right.$ or SRP) on fungal biomass stoichiometry were analyzed by linear regression of $\log _{10}$-transformed data. For each data point, three replicate samples originating from three flasks or microcosms were used. The assessment of the degree of elemental homeostasis was based on the homeostatic coefficient, $H$ :

$$
H=\frac{\log _{10}(x)}{\log _{10}(y)-\log _{10}(\mathrm{c})}
$$

where $x$ is the resource (medium) nutrient stoichiometry (for example, C:P, C:N or N:P ratio), $y$ is the fungal nutrient stoichiometry and $\mathrm{C}$ is a constant (Sterner and Elser, 2002; Persson et al., 2010). We 

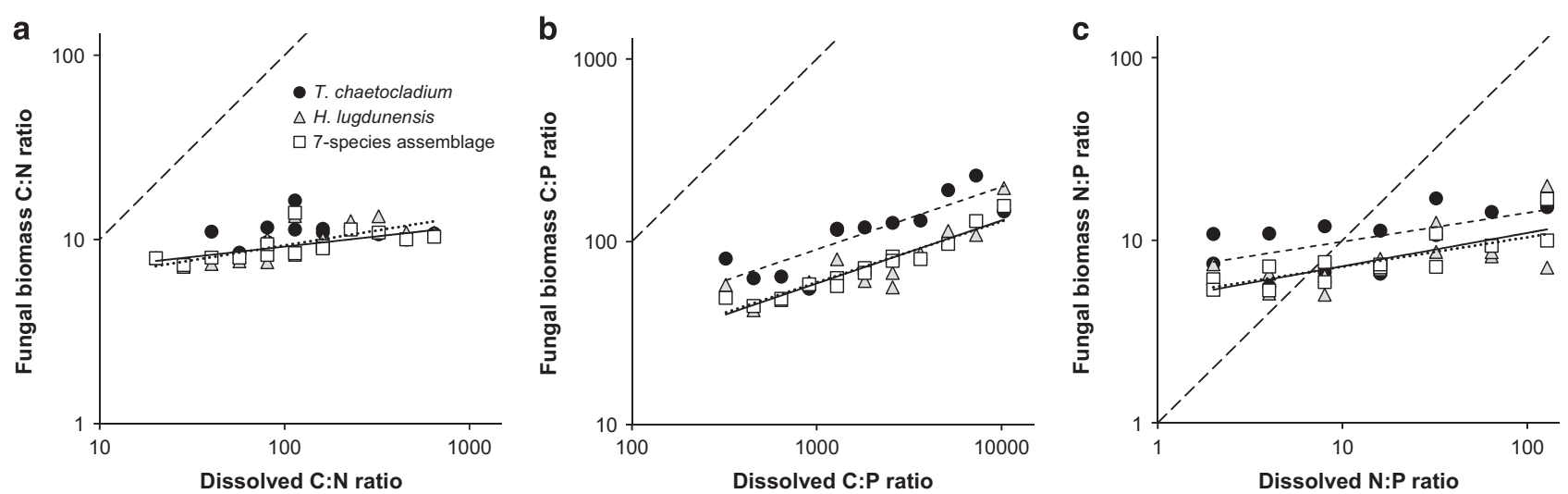

Figure 2 Relationships between nutrient ratios (molar) in liquid media (Experiment 1) and (a) C:N, (b) C:P and (c) N:P stoichiometry of fungal biomass. Slopes (1/H values, see Table 1) between dissolved C:N ratio and fungal biomass C:N were either non-significant or less steep (linear regressions, TC $R^{2}=0.001, P=0.92$; HL $R^{2}=0.53, P=0.003$; assemblage $R^{2}=0.41, P=0.013$ ) when compared to observed slopes between dissolved C:P ratio and fungal biomass C:P (TC and HL $R^{2}=0.72, P<0.001$; assemblage $R^{2}=0.92, P<10^{-7}$ ) or between dissolved N:P ratio and fungal biomass N:P $\left(\right.$ TC $R^{2}=0.35, P=0.043 ; \mathrm{HL} R^{2}=0.42, P=0.012$; assemblage $\left.R^{2}=0.70, P<0.001\right)$. Means of three replicates are shown. Dashed lines represent 1:1 ratio.

Table 1 Summary of biomass nutrient stoichiometry and degree of elemental homeostasis in aquatic fungi grown in Experiment 1 (liquid media) and Experiment 2 (leaf litter substrate)

\begin{tabular}{|c|c|c|c|c|c|c|c|c|c|}
\hline & \multicolumn{3}{|c|}{ C:N ratio } & \multicolumn{3}{|c|}{ C:P ratio } & \multicolumn{3}{|c|}{$N: P$ ratio } \\
\hline & range & mean & $1 / H$ & range & mean & $1 / H$ & range & mean & $1 / H$ \\
\hline \multicolumn{10}{|l|}{ Experiment 1 (liquid media) } \\
\hline T. chaetocladium & $8.2-16.5$ & 11.2 & $0.01^{\mathrm{a}}$ & $50-408$ & 122 & 0.34 & $5.3-28.9$ & 10.9 & 0.16 \\
\hline H. lugdunensis & $7.0-14.4$ & 9.7 & 0.16 & $37-205$ & 80 & 0.33 & $3.4-21.5$ & 8.3 & 0.16 \\
\hline Seven-species assemblage & $6.9-14.2$ & 9.4 & 0.11 & $36-166$ & 78 & 0.34 & $4.0-19.1$ & 8.2 & 0.18 \\
\hline \multicolumn{10}{|l|}{ Experiment 2 (leaf litter) } \\
\hline T. chaetocladium & $8.0-23.5$ & 14.6 & - & $26-466$ & 151 & - & $2.2-34.0$ & 10.2 & 0.53 \\
\hline H. lugdunensis & $3.1-9.0$ & 5.9 & - & $31-196$ & 76 & - & $4.0-31.8$ & 13.3 & 0.50 \\
\hline Six-species assemblage & $6.7-27.2$ & 13.3 & - & $21-228$ & 86 & - & $1.5-14.2$ & 6.8 & 0.31 \\
\hline
\end{tabular}

$1 / H$ values of 0 correspond to strict homeostasis, while values approaching 1 would indicate non-homeostasis or stoichiometric plasticity.

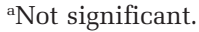

calculated $1 / H$, which is the slope of the regression between $\log _{10}(x)$ and $\log _{10}(y)$ and varies between 0 and 1 . Microorganisms with $1 / H$ approaching 0 are considered strictly homeostatic and those with $1 / H$ approaching 1 are highly plastic with respect to their biomass elemental ratios (Persson et al., 2010). Regression slopes $(1 / H)$ with respect to C:nutrient ratios were calculated separately for $T$. chaetocladium, $H$. lugdunensis and multispecies fungal assemblages.

\section{Results}

Experiment 1. Aquatic fungi grown in liquid media Fungal biomass C:N ratios ranged from 6.9 to 16.5 in different treatments (Figure 2a, Table 1). However, dissolved C:N ratio had no or only small effect on C: $\mathrm{N}$ of fungal biomass (linear regressions, TC $R^{2}=0.001, P=0.92$; HL $R^{2}=0.53, P=0.003$; assemblage $R^{2}=0.41, P=0.013$ ), with all $1 / H$ values being $<0.16$, indicating relatively strict homeostasis. In contrast, fungal C:P ratios increased sharply at lower
$\mathrm{P}$ availability or higher C:P ratio of the medium (TC and HL $R^{2}=0.72, P<0.001$; assemblage $R^{2}=0.92$, $P<10^{-7}$ ), with all $1 / H$ coefficients $>0.33$, indicating higher plasticity (Figure 2b, Table 1). Fungal C:P ratios ranged from 36 to 408 depending on $\mathrm{P}$ availability and fungal species. The N:P ratio of the medium also affected N:P ratios of fungal biomass (TC $R^{2}=0.35, P=0.043 ; \quad H L R^{2}=0.42, P=0.012$; assemblage $\left.R^{2}=0.70, P<0.001\right)$. However, the $1 / H$ values (range 0.16-0.18) were considerably lower than those for fungal C:P. Overall, under the varying $\mathrm{N}: \mathrm{P}$ ratios and levels of nutrient concentrations in the medium, fungal biomass $\mathrm{N}: \mathrm{P}$ ratios ranged from 3.4 to 28.9 (Figure 2c, Table 1).

Experiment 2. Aquatic fungi grown on leaf litter in microcosms simulating stream conditions

Fungal biomass stoichiometry was estimated as the ratio of fungal $\mathrm{C}$ produced to the amount of nutrient taken up during the same time period. Overall, fungal biomass C:N ratios (molar) ranged from 3.1 to 27.2 (Table 1, Figure 3a, Supplementary Figure S1), 

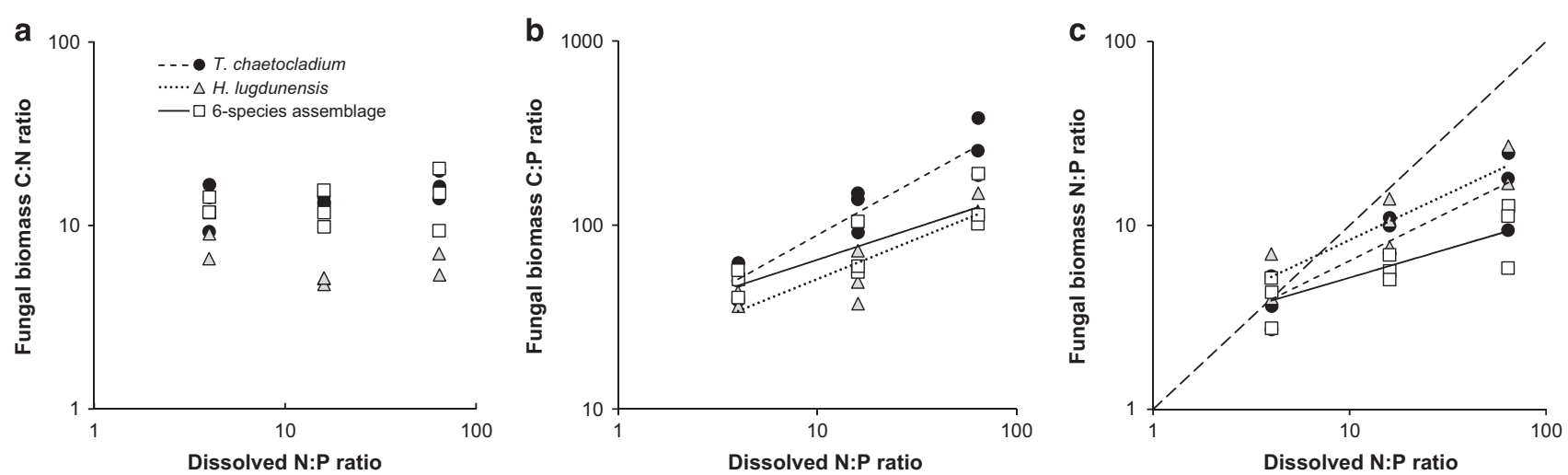

Figure 3 Effects of dissolved N:P ratios (molar) on elemental stoichiometry of fungal biomass associated with decaying leaf litter (Experiment 2). Dissolved N:P ratios did not affect (a) fungal biomass C:N (linear regressions, $R^{2}=0.05-0.25, P=0.17-0.57$ ), but positively affected (b) fungal biomass C:P (TC $R^{2}=0.89, P<0.001$; HL $R^{2}=0.76, P=0.011$; assemblage $R^{2}=0.72, P=0.004$ ) and (c) fungal biomass N:P (TC $R^{2}=0.79, P=0.001$; HL $R^{2}=0.81, P=0.006$; assemblage $R^{2}=0.65, P=0.009$ ) indicating that fungi were not homeostatic with respect to their C:P and N:P ratios. Means of three replicates are shown. Dashed line represents 1:1 ratio.

depending on the fungal species (or assemblage) and dissolved nutrient availability. $H$. lugdunensis had the lowest mycelial $\mathrm{C}: \mathrm{N}$ ratio, that is, its biomass was the most N-rich, while T. chaetocladium and the 6-species fungal assemblage had C:N ratios generally above 10. However, there was no significant effect of dissolved N:P ratio or $\mathrm{NO}_{3}-\mathrm{N}$ concentration on fungal C:N (Figure 3; linear regressions, $P>0.05)$. Thus, litter-associated fungi were also relatively homeostatic with respect to their C:N ratio.

Fungal C:P ranged from 21 to 466 (Table 1, Figure 3b, Supplementary Figure S1) depending on fungal species (or assemblage) and nutrient availability. Both dissolved N:P ratios (Figure 3; linear regression, TC $R^{2}=0.89, P<0.001 ; \mathrm{HL} R^{2}=0.76$, $P=0.011$; assemblage $\left.R^{2}=0.72, P=0.004\right)$ and SRP concentrations (all treatments combined, $R^{2}=0.34$, $P=0.002$ ) affected fungal C:P ratios. Thus, litterassociated fungi were not homeostatic with respect to their C:P ratio.

Fungal N:P ranged from 1.5 to 34 (Table 1, Figure 3, Supplementary Figure S1), being lowest on average for the six-species assemblage. Dissolved $\mathrm{N}: \mathrm{P}$ ratios had a significant effect on fungal biomass $\mathrm{N}: \mathrm{P}\left(\mathrm{TC} R^{2}=0.79, P=0.001\right.$; HL $R^{2}=0.81, P=0.006$; assemblage $R^{2}=0.65, P=0.009$ ). Nitrate-N concentration did not affect fungal N:P ratio, while higher SRP resulted in lower fungal N:P (all treatments combined, $R^{2}=0.31, P=0.004$ ). The overall pattern was somewhat similar to the relationship between dissolved nutrients and fungal C:P, suggesting that $\mathrm{P}$ rather than $\mathrm{N}$ drove fungal $\mathrm{N}: \mathrm{P}$ ratios. In all treatments, fungi were not homeostatic with respect to their $\mathrm{N}: \mathrm{P}$ ratios, as the $1 / \mathrm{H}$ coefficient varied from 0.31 to 0.53 .

Fungal growth rates and production were stimulated by dissolved $\mathrm{NO}_{3}-\mathrm{N}$ availability (Figures $4 \mathrm{~b}$ and c, TC $R^{2}=0.88$ and 0.89; HL $R^{2}=0.88$ and 0.79; assemblage $R^{2}=0.76$ and 0.85 , respectively, $P \leqslant 0.002$ in all cases). Fungal growth rates were also strongly correlated with fungal nitrate-N uptake rates (Figure 4a, TC $R^{2}=0.79, \quad P=0.001 ; \quad \mathrm{HL}$ $R^{2}=0.78, P=0.008$; assemblage $R^{2}=0.66, P=0.008$ ). No effects of inorganic $P$ uptake rate or SRP concentration on fungal growth rate or production were found (Figures $4 \mathrm{~d}-\mathrm{f}$ ).

We found a significant positive relationship between fungal growth rate and biomass $\mathrm{C}: \mathrm{N}$ when all data were analyzed together (Figure $5 \mathrm{a}, R^{2}=0.48$, $p<0.001$ ), but not for individual taxa or the sixspecies assemblage, again suggesting that $\mathrm{C}: \mathrm{N}$ ratios are not flexible within taxa. We also found no relationship between fungal growth rates for individual species or multi-species assemblages and their C:P ratios or $\mathrm{P}$ content (Figure $5 \mathrm{~b}$ ).

\section{Discussion}

Aquatic fungi are intimately associated with plant litter, making physical separation of fungal biomass from its natural substrate impossible. Aquatic fungi also obtain $\mathrm{N}$ and $\mathrm{P}$ from both their substrate and the water column (Suberkropp, 1995; Gulis et al., 2006), complicating estimation of their biomass nutrient ratios and assessment of elemental homeostasis (Cherif and Loreau, 2007; Fanin et al., 2013). Using a radioactive tracer (Experiment 2) allowed us to measure fungal production (C accrual), providing the first estimates of nutrient stoichiometry and homeostasis in fungi grown on natural substrates under realistic nutrient concentrations. Both $\mathrm{N}$ and $\mathrm{P}$ were kept at concentrations commonly found in streams, and our corresponding fungal biomass accrual on leaf litter was comparable to values from natural plant litter in streams (Gessner et al., 2007), suggesting that our results are ecologically meaningful. Moreover, our results from Experiment 1 using a soluble, relatively recalcitrant $\mathrm{C}$ source (carboxymethylcellulose) were surprisingly similar to those obtained with the radioactive tracer, despite different approaches. 

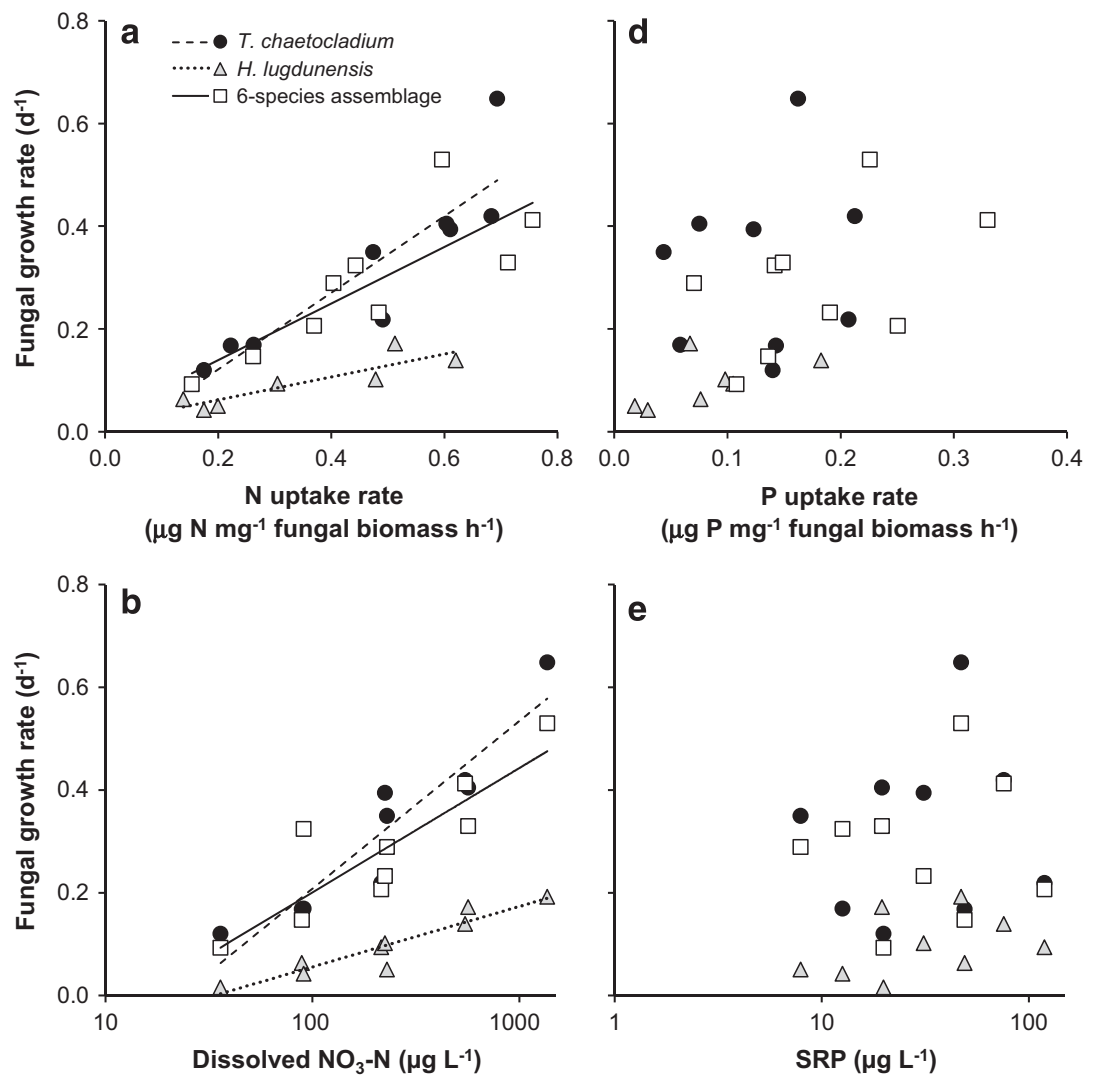

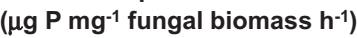
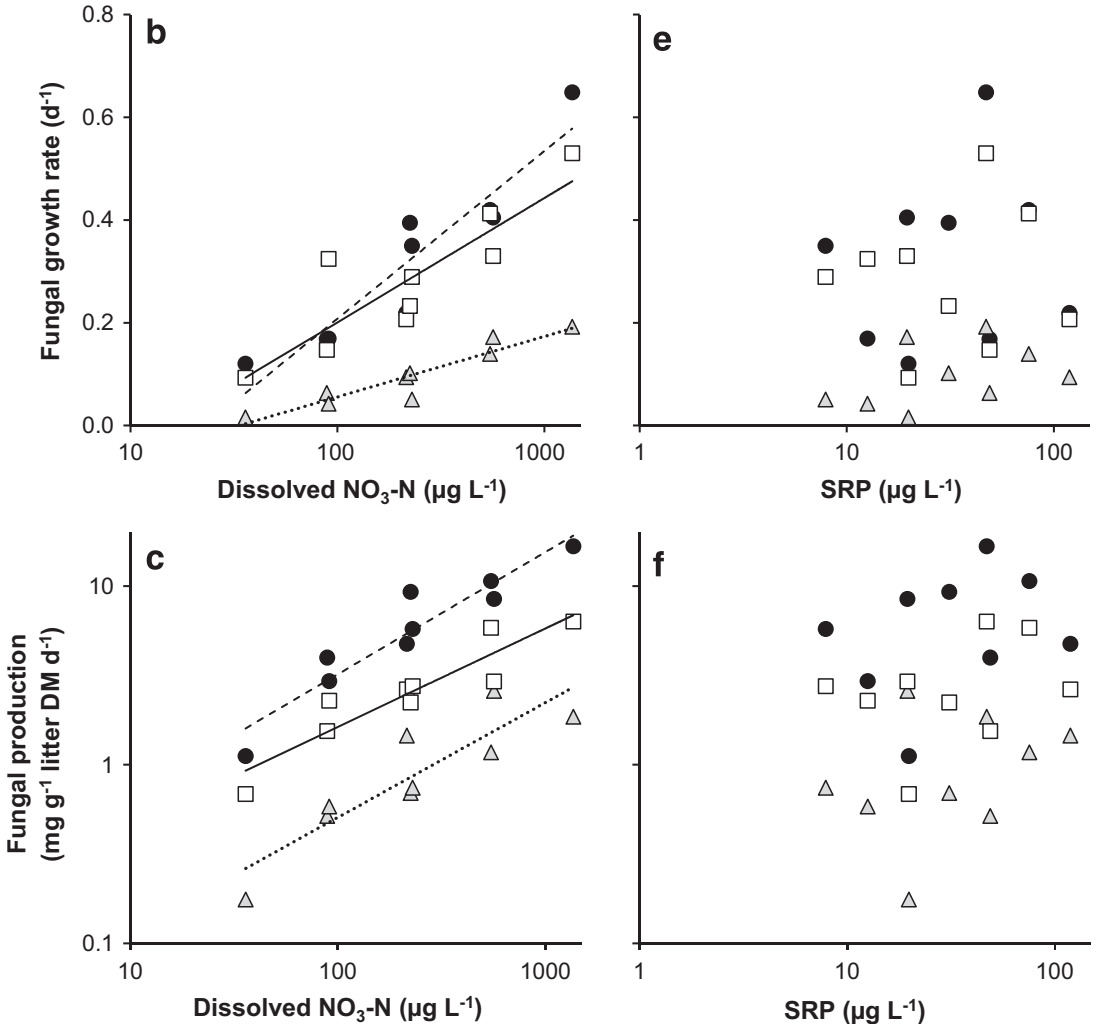

Figure 4 Relationships between dissolved inorganic $\mathrm{N}$ and $\mathrm{P}$ availability or uptake rates and fungal growth rates or production associated with decaying leaf litter. Elevated $\mathrm{NO}_{3}-\mathrm{N}$ uptake rates (a) led to faster fungal growth rates (linear regression, TC $R^{2}=0.79, P=0.001 ; \mathrm{HL}$ $R^{2}=0.78, P=0.008$; assemblage $\left.R^{2}=0.66, P=0.008\right)$. Similar positive relationships were found for dissolved $\mathrm{NO}_{3}-\mathrm{N}^{2}$ concentrations and fungal growth rates (b) (TC $R^{2}=0.88, P<0.001$; HL $R^{2}=0.88, P<0.001$; assemblage $R^{2}=0.76, P=0.002$ ) and production (c) (TC $R^{2}=0.89$; HL $R^{2}=0.79$; assemblage $R^{2}=0.85, P \leqslant 0.001$ in all cases). No effects of inorganic P uptake rate or SRP concentration on fungal growth rates or production were found (d-f, $P \geqslant 0.17$ in all cases).

The range of fungal C:N ratios in our experiments (3.1-27.2; Table 1) was broader than that reported in physiological experiments using rich liquid media with labile C sources (12.4-30.6; Danger and Chauvet, 2013; Grimmett et al., 2013) and was affected by species identity (we found very low C:N ratios of $H$. lugdunensis in Experiment 2). Fungal C:P ratios ranged from 21 to 466 and were generally lower than values reported by Danger and Chauvet (2013) and Grimmett et al. (2013) (76-1499), but broadly comparable to those of terrestrial litterassociated fungi (Mouginot et al., 2014). We also found generally lower fungal N:P ratios (1.5-34.0) than those published previously. In our experiments, $\mathrm{N}: \mathrm{P}$ ratios of multi-species fungal assemblages appeared somewhat less variable than those observed for single species, however, we found no significant differences in the degree of $\mathrm{N}: \mathrm{P}$ and $\mathrm{C}: \mathrm{P}$ non-homeostasis among the multi-species assemblages and monocultures (Figures 2b,c and 3c, Table 1, comparisons of slopes, $P>0.59$ ). Published indirect estimates of fungal $\mathrm{C}: \mathrm{N}$ ratios from aquatic ecosystems or for aquatic microbial communities dominated by fungi have yielded a relatively narrow 


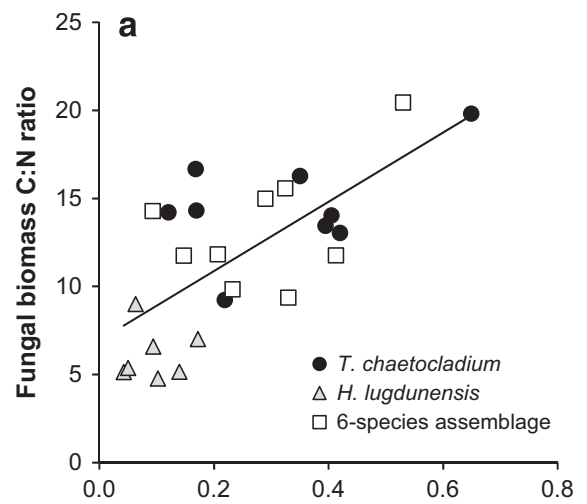

However, fungi can also acquire $\mathrm{N}$ and $\mathrm{P}$ from their organic substrates (such as leaf litter), and these fluxes into fungal biomass were not accounted for in our calculations. However, mining $\mathrm{N}$ and $\mathrm{P}$ from plant litter requires considerable energy expenditures to produce enzymes to attack complex organic molecules and cleave amino or phosphate groups (Sinsabaugh and Follstad Shah, 2012; Sinsabaugh et al., 2014). Thus from an energetic standpoint, aquatic fungi are expected to rely heavily on dissolved inorganic $\mathrm{N}$ and $\mathrm{P}$, if they are available. Indeed, recent experimental estimates of the importance of dissolved vs litter-derived N (Cheever et al., 2013) suggest that the dissolved inorganic pool is by far the major N source for aquatic fungi. Moreover, $\mathrm{N}$ and $\mathrm{P}$ mineralization at early to mid-stages of decomposition (Experiment 2) was likely very low, and it is now well established that dissolved $\mathrm{N}$ and $\mathrm{P}$ in nutrient-addition experiments stimulate fungal activity, leading to considerable net nutrient immobilization (Gulis and Suberkropp, 2003a; Ferreira et al., 2006; Gulis et al., 2006; Cornut et al., 2015). Small uncertainties in our estimates of fungal biomass (and C) due to interspecific variability in ergosterol content may have also affected our estimates of fungal C:nutrient ratios. To minimize this effect, we used a specific conversion factor of $4.5 \mathrm{mg}$ ergosterol per $\mathrm{g}$ of fungal biomass for $H$. lugdunensis, while an average conversion factor (5.5 mg per g) was used for the other treatments, including our six-species assemblage (Gessner and Chauvet, 1993; Raviraja et al., 2004).

While aquatic fungi maintained relatively constant C:N ratios regardless of changes in resource stoichiometry or dissolved $\mathrm{N}$ concentration (that is, homeostasis), fungal C:P and, hence, N:P ratios varied significantly depending on dissolved $\mathrm{C}: \mathrm{P}$ and $\mathrm{N}: \mathrm{P}$ ratios and absolute $\mathrm{P}$ availability, suggesting plasticity of P content. Danger and Chauvet (2013) also reported non-homeostasis of C:P and N:P in aquatic hyphomycetes in high-P liquid cultures, with $1 / H$ values slightly higher (0.55-0.75) than those reported here for the experiment using leaf litter. The non-homeostatic pattern in fungal C:P and $\mathrm{N}: \mathrm{P}$ ratios suggests the possibility of $\mathrm{P}$ storage (for example, in the form of polyphosphates) when dissolved $\mathrm{P}$ is plentiful, as has been observed in stream periphyton (Rier et al., 2016). Grimmett et al. (2013) reported no correlation between RNA and DNA content and $\mathrm{P}$ content in aquatic fungi, supporting the notion of $\mathrm{P}$ storage. In terrestrial fungi, $\mathrm{P}$ content may also be flexible, since different groups of fungi can retain and store excess, metabolically inactive $\mathrm{P}$ during periods of luxury supply (Beever and Burns, 1980; Bucking and Heyser, 1999).

Non-homeostasis of C:P and N:P ratios in aquatic fungi parallels recent findings for aquatic heterotrophic bacteria. While some studies suggested relative homeostasis in aquatic bacteria (Makino et al., 2003; Makino and Cotner, 2004), experiments with bacterial assemblages from different lakes 
showed highly variable $\mathrm{P}$ content and marked nonhomeostasis of C:P and N:P ratios (Tezuka, 1990; Cotner et al., 2010; Godwin and Cotner, 2015). For example, Godwin and Cotner (2015) reported C:N:P of bacterial assemblages from lakes to range from 28:7:1 to as high as $8500: 1200: 1$ under severe $\mathrm{P}$ limitation.

Responses of natural assemblages of heterotrophic microorganisms may deviate from homeostasis due to differences in optimal cellular N:P ratio and nutrient demand among microbial taxa, resulting in shifts in community structure across gradients of $\mathrm{N}$ and $\mathrm{P}$ availability (Tezuka, 1990; Chrzanowski et al., 1996; Makino and Cotner, 2004; Godwin and Cotner, 2014). While such shifts have already been documented for aquatic bacteria, only circumstantial evidence exists for fungi. Changes in dominance patterns among aquatic hyphomycetes associated with leaf litter have been observed in response to whole-stream nutrient enrichment $(\mathrm{N}+\mathrm{P})$ (Gulis and Suberkropp, 2003a, 2004). Such changes in assemblage composition may drive shifts in both fungal and detrital stoichiometry. Fungal biomass can account for up to 18-23\% of total detrital mass (Suberkropp, 1995), and it is nutrient-rich (low C:nutrient ratio) compared to uncolonized plant litter. Fungal biomass accrual and associated immobilization of dissolved nutrients as litter decomposes leads to decreases in C:N and C:P ratios of detritus and hence increased resource quality for detritivores (Cornut et al., 2015). Since detritivorous invertebrates prefer to consume litter colonized by fungi, and even favor patches colonized by particular fungal species (Suberkropp, 1992), nutrient immobilization and variable fungal C:P and N:P may have strong effects on food quality and nutrient transfer to detritivores and higher trophic levels (Manning et al., 2016).

We found no relationship between fungal growth rates on plant litter for individual fungal species or multi-species assemblages and their C:P ratios or $\mathrm{P}$ content. The Growth Rate Hypothesis (GRH; Sterner and Elser, 2002; Elser et al., 2003) suggests that organisms with higher growth rates show higher $\mathrm{P}$ content (lower C:P ratios) due to faster rates of metabolism and protein synthesis that require higher concentrations of P-rich RNA. A plausible explanation for any lack of relationship between growth rate and fungal C:P may be (i) P storage and/ or (ii) nutrient limitation. Hence, the GRH may not be valid under conditions of $\mathrm{N}$ limitation (Franklin et al., 2011) or, in the case of aquatic fungi, when either dissolved $\mathrm{N}$ or $\mathrm{P}$ (or both) are limiting, so that fungi switch from relying on dissolved nutrients to mining $\mathrm{N}$ and $\mathrm{P}$ from plant litter. Grimmet et al. (2013) explicitly tested the GRH in several aquatic hyphomycetes in liquid cultures and also found no evidence to support it. Since a similar lack of support for the GRH has been reported for microalgae (Flynn et al., 2010) and aquatic heterotrophic bacteria when P-limitation was relaxed (Makino and Cotner, 2004), the broad applicability of the
GRH to aquatic microbial communities may be limited. Interestingly, we saw a positive relationship between fungal growth rate and biomass C:N when all data were analyzed together, suggesting that the fastest growing taxa have the highest nutrient use efficiency (that is, can build biomass with the highest $\mathrm{C}: \mathrm{N}$ ratios), but within taxa, $\mathrm{C}: \mathrm{N}$ is not flexible.

Our findings of the positive effect of dissolved N, but not $\mathrm{P}$, on fungal growth rates add to other data (Cheever et al., 2012, 2013; Gulis et al., unpublished) suggesting that fungal activity, but not C:N ratio, is driven by dissolved $\mathrm{N}$ availability. Conversely, fungal biomass C:P and N:P stoichiometry, but not activity, was driven by dissolved $\mathrm{P}$ availability, probably via luxury $\mathrm{P}$ uptake and storage. These findings have important implications for our understanding of organic matter processing and stream ecosystem functioning. Fungi may stabilize the stoichiometry of detritus and facilitate nutrient transfer to detritivorous invertebrates. $\mathrm{N}$ limitation (for example, low dissolved $\mathrm{N}: \mathrm{P}$ ratios) would theoretically decrease fungal growth and litter decomposition rates. However, even when fungal biomass is relatively low, luxury P uptake by fungi would decrease litter C:P ratios and make detritus more palatable to detritivores. Conversely, P limitation (such as high dissolved N:P ratios common in many polluted streams) should not strongly constrain fungal growth and microbial litter decomposition rates. In this scenario, when fungal biomass is high but P-poor, detrital C:P ratio would still be decreased sufficiently to provide palatable resources to detritivores. Even though the effects of dissolved $\mathrm{N}$ and $\mathrm{P}$ may occur via different pathways (via changing litter associated biomass or its nutrient content), fungi-mediated shifts in detrital stoichiometry are a critical nexus for the effects of nutrients on litter breakdown and associated metazoans (Manning et al., 2015).

Our results demonstrate that aquatic fungi have $\mathrm{N}$ and $\mathrm{P}$ content and $\mathrm{C}: \mathrm{N}, \mathrm{C}: \mathrm{P}$ and $\mathrm{N}: \mathrm{P}$ ratios intermediate to those reported for algae and bacteria, which can be explained by the overall metabolic activities or growth rates typical of these microbial groups (fastest in the case of bacteria and slowest for algae). However, while the aquatic fungi in our experiments were capable of maintaining nearly constant biomass $\mathrm{C}: \mathrm{N}$ ratio, regardless of changes in resource stoichiometry or absolute concentrations of dissolved N, fungal C:P ratio varied depending on $\mathrm{N}$ : $\mathrm{P}$ supply ratio and $\mathrm{P}$ concentration. Thus, aquatic fungi are relatively homeostatic with respect to their biomass C:N ratio, but flexible with respect to their $\mathrm{C}: \mathrm{P}$ and $\mathrm{N}: \mathrm{P}$ ratios. The ability of aquatic fungi to immobilize and store $\mathrm{P}$ when it becomes available due to excessive nutrient loading may alter the flow of nutrients through aquatic food webs and affect ecosystem functioning, since many aquatic detritivores rely on litter-associated microorganisms as sources of $\mathrm{C}, \mathrm{N}$ and $\mathrm{P}$. 


\section{Conflict of Interest}

The authors declare no conflict of interest.

\section{Acknowledgements}

We thank Rong Su for assistance with HPLC of radiolabeled ergosterol samples. Financial support from the National Science Foundation (DEB 0919054 to VG and DBI 0923063 to KAK) is gratefully acknowledged.

\section{References}

Allan JD. (1995). Stream Ecology: Structure and Function of Running Waters. Chapman and Hall: London.

Anderson JM. (1976). An ignition method for determination of total phosphorus in lake sediments. Water Res 10: 329-331.

APHA (1995). Standard Methods for the Examination of Water and Wastewater. 19th edn. American Public Health Association: Washington, DC.

Beever RE, Burns DJW. (1980). Phosphorus uptake, storage and utilization by fungi. Adv Bot Res 8: 127-219.

Bucking H, Heyser W. (1999). Elemental composition and function of polyphosphates in ectomycorrhizal fungian X-ray microanalytical study. Mycol Res 103: 31-39.

Cheever BM, Kratzer EB, Webster JR. (2012). Immobilization and mineralization of $\mathrm{N}$ and $\mathrm{P}$ by heterotrophic microbes during leaf decomposition. Freshwat Sci 31: 133-147.

Cheever BM, Webster JR, Bilger EE, Thomas SA. (2013). The relative importance of exogenous and substratederived nitrogen for microbial growth during leaf decomposition. Ecology 94: 1614-1625.

Cherif M, Loreau M. (2007). Stoichiometric constraints on resource use, competitive interactions, and elemental cycling in microbial decomposers. Am Nat 169: 709-724.

Chrzanowski TH, Kyle M, Elser JJ, Sterner RW. (1996). Element ratios and growth dynamics of bacteria in an oligotrophic Canadian shield lake. Aquat Microb Ecol 11: 119-125.

Cornut J, Ferreira V, Gonçalves A, Chauvet E, Canhoto C. (2015). Fungal alteration of the elemental composition of leaf litter affects shredder feeding activity. Freshw Biol 60: 1755-1771.

Cotner JB, Hall EK, Scott JT, Heldal M. (2010). Freshwater bacteria are stoichiometrically flexible with a nutrient composition similar to seston. Front Microbiol 1: 132.

Cross WF, Wallace JB, Rosemond AD. (2007). Nutrient enrichment reduces constraints on material flows in a detritus-based food web. Ecology 88: 2563-2575.

Cross WF, Wallace JB, Rosemond AD, Eggert SL. (2006). Whole-system nutrient enrichment increases secondary production in a detritus-based ecosystem. Ecology 87: 1556-1565.

Danger M, Gessner MO, Bärlocher F. (2016). Ecological stoichiometry of aquatic fungi: current knowledge and perspectives. Fungal Ecol 19: 100-111.

Danger M, Chauvet E. (2013). Elemental composition and degree of homeostasis of fungi: are aquatic hyphomycetes more like metazoans, bacteria or plants? Fungal Ecol 6: 453-457.

Dodds WK, Welch EB. (2000). Establishing nutrient criteria in streams. J N Am Benthol Soc 19: 186-196.
Elser J, Acharya K, Kyle M, Cotner J, Makino W, Markow T et al. (2003). Growth rate-stoichiometry couplings in diverse biota. Ecol Lett 6: 936-943.

Enriquez S, Duarte C, Sand-Jensen K. (1993). Patterns in decomposition rates among photosynthetic organisms: the importance of detritus C:N:P content. Oecologia 94: 457-471.

Fanin N, Fromin N, Buatois B, Hattenschwiler S. (2013). An experimental test of the hypothesis of nonhomeostatic consumer stoichiometry in a plant littermicrobe system. Ecol Lett 16: 764-772.

Ferreira V, Gulis V, Graça M. (2006). Whole-stream nitrate addition affects litter decomposition and associated fungi but not invertebrates. Oecologia 149: 718-729.

Findlay SEG, Dye S, Kuehn KA. (2002). Microbial growth and nitrogen retention in litter of Phragmites australis compared to Typha angustifolia. Wetlands 22: 616-625.

Flynn K, Raven J, Rees T, Finkel Z, Quigg A, Beardall J. (2010). Is the growth rate hypothesis applicable to microalgae? J Phycol 46: 1-12.

Franklin O, Hall EK, Kaiser C, Battin TJ, Richter A. (2011). Optimization of biomass composition explains microbial growth-stoichiometry relationships. Am Nat 177: E29-E42.

Gessner MO. (2005) Ergosterol as a measure of fungal biomass. In: Graça MAS, Bärlocher F, Gessner MO (eds). Methods to Study Litter Decomposition: a Practical Guide. Springer: Dordrecht, The Netherlands, pp 189-195.

Gessner MO, Chauvet E. (1993). Ergosterol-to-biomass conversion factors for aquatic hyphomycetes. Appl Environ Microbiol 59: 502-507.

Gessner MO, Chauvet E. (1997). Growth and production of aquatic hyphomycetes in decomposing leaf litter. Limnol Oceanogr 42: 496-595.

Gessner MO, Gulis V, Kuehn KA, Chauvet E, Suberkropp K. (2007). Fungal decomposers of plant litter in aquatic ecosystems. In: Kubicek CP, Druzhinina IS (eds). The Mycota, Vol IV, Environmental and Microbial Relationship. Springer: Berlin, pp 301-324.

Gessner MO, Schmitt AL. (1996). Use of solid-phase extraction to determine ergosterol concentrations in plant tissue colonized by fungi. Appl Environ Microbiol 62: 415-419.

Godwin CM, Cotner JB. (2014). Carbon:phosphorus homeostasis of aquatic bacterial assemblages is mediated by shifts in assemblage composition. Aquat Microb Ecol 73: 245-258.

Godwin CM, Cotner JB. (2015). Aquatic heterotrophic bacteria have highly flexible phosphorus content and biomass stoichiometry. ISME J 9: 2324-2327.

Grimmett I, Shipp K, Macneil A, Bärlocher F. (2013). Does the growth rate hypothesis apply to aquatic hyphomycetes? Fungal Ecol 6: 493-500.

Gulis V, Kuehn KA, Suberkropp K. (2006). The role of fungi in carbon and nitrogen cycles in freshwater ecosystems. In: Gadd GM (ed.). Fungi in Biogeochemical Cycles. Cambridge University Press: Cambridge, pp 404-435.

Gulis V, Suberkropp K. (2003a). Leaf litter decomposition and microbial activity in nutrient-enriched and unaltered reaches of a headwater stream. Freshw Biol 48: 123-134.

Gulis V, Suberkropp K. (2003b). Effect of inorganic nutrients on relative contributions of fungi and 
bacteria to carbon flow from submerged decomposing leaf litter. Microb Ecol 45: 11-19.

Gulis V, Suberkropp K. (2003c). Interactions between stream fungi and bacteria associated with decomposing leaf litter at different levels of nutrient availability. Aquat Microb Ecol 30: 149-157.

Gulis V, Suberkropp K. (2004). Effects of whole-stream nutrient enrichment on the concentration and abundance of aquatic hyphomycete conidia in transport. Mycologia 96: 57-65.

Gulis V, Suberkropp K, Rosernond A. (2008). Comparison of fungal activities on wood and leaf litter in unaltered and nutrient-enriched headwater streams. Appl Environ Microbiol 74: 1094-1101.

Kuehn K. (2016). Lentic and lotic habitats as templets for fungal communities: traits, adaptations, and their significance to litter decomposition within freshwater ecosystems. Fungal Ecol 19: 135-154.

Makino W, Cotner JB. (2004). Elemental stoichiometry of a heterotrophic bacterial community in a freshwater lake: implications for growth- and resourcedependent variations. Aquat Microb Ecol 34: 33-41.

Makino W, Cotner JB, Sterner RW, Elser JJ. (2003). Are bacteria more like plants or animals? Growth rate and resource dependence of bacterial C:N:P stoichiometry. Funct Ecol 17: 121-130.

Manning DWP, Rosemond AD, Kominoski JS, Gulis V, Benstead JP, Maerz JC. (2015). Detrital stoichiometry as a critical nexus for the effects of streamwater nutrients on leaf litter breakdown rates. Ecology 96: 2214-2224.

Manning DWP, Rosemond AD, Gulis V, Benstead JP, Kominoski JS, Maerz JC. (2016). Convergence of detrital stoichiometry predicts thresholds of nutrientstimulated breakdown in streams. Ecol Appl 26: 1745-1757.

Millennium Ecosystem Assessment. (2005). Ecosystems and Human Well-Being: Synthesis. Island Press: Washington, DC.

Mouginot C, Kawamura R, Matulich KL, Berlemont R, Allison SD, Amend AS, Martiny AC. (2014). Elemental stoichiometry of Fungi and Bacteria strains from grassland leaf litter. Soil Biol Biochem 76: 278-285.

Newell SY, Statzell-Tallman A. (1982). Factors for conversion of fungal biovolume values to biomass, carbon and nitrogen: variation with mycelial ages, growth conditions, and strains of fungi from a salt marsh. Oikos 39: 261-268.

Olsson P, Hammer E, Wallander H, Pallon J. (2008). Phosphorus availability influences elemental uptake in the mycorrhizal fungus Glomus intraradices, as revealed by particle-induced X-ray emission analysis. Appl Environ Microbiol 74: 4144-4148.

Persson J, Fink P, Goto A, Hood J, Jonas J, Kato S. (2010). To be or not to be what you eat: regulation of stoichiometric homeostasis among autotrophs and heterotrophs. Oikos 119: 741-751.

Raviraja NS, Nikolcheva LG, Bärlocher F. (2004). Pellet size affects mycelial ergosterol content in aquatic hyphomycetes. Mycologia 96: 388-392.

Redfield AC. (1958). The biological control of chemical factors in the environment. Am Sci 46: 205-221.

Rier ST, Kinek KC, Hay SE, Francoeur SN. (2016). Polyphosphate plays a vital role in the phosphorus dynamics of stream periphyton. Freshwat Sci 35: 490-502.

Rosemond AD, Benstead JP, Bumpers PM, Gulis V, Kominoski JS, Manning DWP et al. (2015). Experimental nutrient additions accelerate terrestrial carbon loss from stream ecosystems. Science 347: 1142-1145.

Sanzone DM, Tank JL, Meyer JL, Mulholland PJ, Findlay SEG. (2001). Microbial incorporation of nitrogen in stream detritus. Hydrobiologia 464: 27-35.

Scott JT, Cotner JB, LaPara TM. (2012). Variable stoichiometry and homeostatic regulation of bacterial biomass elemental composition. Front Microbiol 3: 42.

Sinsabaugh R, Belnap J, Findlay S, Follstad Shah JJ, Hill B, Kuehn K et al. (2014). Extracellular enzyme kinetics scale with resource availability. Biogeochemistry 121: 287-304.

Sinsabaugh RL, Follstad Shah JJ. (2012). Ecoenzymatic stoichiometry and ecological theory. Annu Rev Ecol Evol Syst 43: 313-343.

Sinsabaugh RL, Follstad Shah JJ, Findlay SG, Kuehn KA, Moorhead DL. (2015). Scaling microbial biomass, metabolism and resource supply. Biogeochemistry 122: 175-190.

Sterner RW, Elser JJ. (2002). Ecological Stoichiometry: The Biology of Elements from Molecules to the Biosphere. Princeton University Press: Princeton, NJ.

Suberkropp K. (1991). Relationships between growth and sporulation of aquatic hyphomycetes on decomposing leaf litter. Mycol Res 95: 843-850.

Suberkropp K. (1992). Interactions with invertebrates. In: Bärlocher F (ed.). The Ecology of Aquatic Hyphomycetes. Springer: Berlin, pp 118-134.

Suberkropp K. (1995). The influence of nutrients on fungal growth, productivity, and sporulation during leaf breakdown in streams. Can J Bot 73: S1361-S1369.

Suberkropp K, Gessner MO. (2005). Acetate incorporation into ergosterol to determine fungal growth rates and production. In: Graça MAS, Bärlocher F, Gessner MO (eds). Methods to Study Litter Decomposition: a Practical Guide. Springer: Dordrecht, The Netherlands, pp 197-202.

Suberkropp K, Gulis V, Rosemond AD, Benstead JP. (2010). Ecosystem and physiological scales of microbial responses to nutrients in a detritus-based stream: results of a 5-year continuous enrichment. Limnol Oceanogr 55: 149-160.

Suberkropp K, Weyers H. (1996). Application of fungal and bacterial production methodologies to decomposing leaves in streams. Appl Environ Microbiol 62: 1610-1615.

Tant CJ, Rosemond AD, First MR. (2013). Stream nutrient enrichment has a greater effect on coarse than on fine benthic organic matter. Freshwat Sci 32: 1111-1121.

Tezuka Y. (1990). Bacterial regeneration of ammonium and phosphate as affected by the carbon:nitrogen:phosphorus ratio of organic substrates. Microb Ecol 19: 227-238.

Wallander H, Johansson L, Pallon J. (2002). PIXE analysis to estimate the elemental composition of ectomycorrhizal rhizomorphs grown in contact with different minerals in forest soil. FEMS Microbiol Ecol 39: 147-156.

Supplementary Information accompanies this paper on The ISME Journal website (http://www.nature.com/ismej) 